\title{
Phospholipid asymmetry during erythropoiesis. A study on Friend erythroleukemic cells and mouse reticulocytes
}

\author{
P.H. Van der Schaft, B. Roelofsen, J.A.F. Op den Kamp \\ and L.L.M. Van Deenen \\ Laboratory of Biochemistry, State University of Utrecht, Padualaan 8, NL-3584 CH Utrecht (The Netherlands)
}

(Received 16 January 1987) Key words: Phospholipid asymmetry; Plasma membrane; Erythropoiesis; (Friend erythroleukemic cell;
Mouse reticulocyte)

The distribution of phospholipids over the outer and inner layers of the plasma membranes of differentiated Friend erythroleukemic cells (Friend cells) and mouse reticulocytes has been determined. Phosphatidylcholine, phosphatidylethanolamine and phosphatidylinositol were found to be distributed symmetrically over both layers, sphingomyelin was found to be enriched in the outer layer (80-85\%) and phosphatidylserine appeared to be present mainly in the inner layer $(80-90 \%)$ of the plasma membranes of differentiated Friend cells. The outer layer of reticulocyte membranes contains $50-60 \%$ of the phosphatidylcholine, $20 \%$ of the phosphatidylethanolamine, $82-85 \%$ of the sphingomyelin and $40-42 \%$ of the phosphatidylinositol. All of the phosphatidylserine is present in the inner layer. The results show, that the asymmetric distribution of phospholipids, typical for erythrocyte membranes, is partially apparent already at an early stage of erythropoiesis, the proerythroblast, while the final organization of phospholipid distribution takes place at some stage during enucleation of the enormoblast and release of the reticulocyte into the blood stream.

\section{Introduction}

The distribution of phospholipids over the two layers of biological membranes has been extensively studied during the last decade, and one of the best examples of a membrane in which an asymmetric phospholipid distribution has been unequivocally established is the erythrocyte membrane [1-3].

An important question related to phospholipid

Abbreviations: DMSO, dimethylsulfoxide; PC, phosphatidylcholine; PS, phosphatidylserine; PE, phosphatidylethanolamine; PI, phosphatidylinositol; SPH, sphingomyelin; LPC, lysophosphatidylcholine; DPG, diphosphatidylglycerol.

Correspondence: J.A.F. Op den Kamp, Laboratory of Biochemistry, State University of Utrecht, Transitorium III, Padualaan 8, Utrecht, NL-3584 CH Utrecht, The Netherlands. asymmetry in erythrocytes is that of its biogenesis. Indeed, the erythrocyte represents the end product of a complex differentiation pathway which requires several days to be completed. During this process, which starts in the bone marrow, proliferating pluripotential stem cells become committed to erythropoiesis and evolute through a succession of developmental stages (proerythroblast, basophilic erythroblast, polychromatophilic erythroblast) to the normoblast stage. Then, upon extrusion of the nucleus, a reticulocyte is formed which enters into the blood circulation, where it completes its maturation to the final erythrocyte stage [4].

One may thus ask what the phospholipid distribution in the plasma membrane of the erythroblast is and whether this distribution is similar (or not) to that existing in the mature erythrocyte. If 
it is different, it is essential to investigate which mechanisms are responsible for the change(s) in phospholipid distribution and at which stage(s) of the differentiation pathway these modifications occur.

We have attempted to answer the first and last of these questions using Friend erythroleukemic cells (Friend cells) and phenylhydrazine induced mouse reticulocytes as experimental systems. Friend cells are erythroid cells, derived from susceptible mouse spleens infected with the Friend virus complex [5], which are blocked at an early stage of their normal differentiation pathway, presumably between the burst forming unit-erythroid stage and the colony forming unit-erythroid stage $[4,6,7]$. These cells which only proliferate under normal growth conditions, can be induced to differentiate at least up to a normoblast-like stage by a variety of chemicals, among which dimethylsulfoxide is most commonly used [8]. The morphological and biochemical characteristics of their developmental program have been intensively investigated and in many respects closely resemble those of the normal erythropoietic pathway $[9,10]$.

In a previous report the phospholipid composition of the plasma membrane of Friend cells has been described. Also the distribution of phospholipids over inner and outer layer of the plasma membrane has been determined and compared with the distribution found in the plasma membrane of mature mouse erythrocytes [11-13]. The present report describes the characteristics of dimethylsulfoxide-differentiated Friend cells (DMSO-Friend cells) and reticulocytes. The various techniques which have been applied to investigate the phospholipid localization include phospholipase $\mathrm{A}_{2}$, phospholipase $\mathrm{C}$ and sphingomyelinase $\mathrm{C}$ treatment, fluorescamine labeling of aminophospholipids and a phosphatidylcholine transfer protein mediated exchange procedure. The data obtained with the different localization techniques were found to be in good agreement with each other and allowed us to narrow down the time period at which the definite phospholipid asymmetry is established during erythropoiesis.

\section{Materials and Methods}

Cells

Friend erythroleukemic cells (derived from clone 745A) were grown in polyethylene Falcon or Costar bottles $\left(175 \mathrm{~cm}^{2}\right.$ surface) containing $50 \mathrm{ml}$ Eagle's minimal essential medium supplemented with $15 \%$ fetal calf serum, penicillin $(100 \mathrm{U} / \mathrm{ml})$, streptomycin $(0.1 \mathrm{mg} / \mathrm{ml})$ and glutamine $(2 \mathrm{mM})$. The medium contained furthermore double concentrations of amino acids and vitamins. Cells were grown at $37^{\circ} \mathrm{C}$ in an incubator at $90 \%$ relative humidity and a $5 \% \mathrm{CO}_{2}$ atmosphere. Cells were induced to differentiate by seeding them into medium containing dimethylsulfoxide (DMSO, $1.8 \%$ (v/v), J.T. Baker Chemicals). Differentiation was measured by determining the percentage of benzidine-positive cells as described by Rifkind et al. [14]. Cells were harvested after 4 or 5 days, centrifuged at $480 \times g$ for $10 \mathrm{~min}$ and washed three times at $37^{\circ} \mathrm{C}$ with buffer $(150 \mathrm{mM} \mathrm{NaCl}, 5$ $\mathrm{mM} \mathrm{KCl}, 1 \mathrm{mM} \mathrm{MgCl}_{2}, 1 \mathrm{mM} \mathrm{CaCl}{ }_{2}, 5 \mathrm{mM}$ glucose and $5 \mathrm{mM}$ Tricine, $\mathrm{pH}$ 7.5). Resuspension of cells was achieved by adding a small amount of buffer and using the up/down pumping action of a Pasteur pipet, taking care to avoid frothing: then, more buffer was added and the cells were centrifuged.

Enhanced production of murine reticulocytes was induced by phenylhydrazine. BALB $/ \mathrm{c}$ or $\mathrm{DBA} / 2 \mathrm{~J}$ mice ( $20 \mathrm{~g}$ body weight) were injected daily with $0.12 \mathrm{ml} 1 \%$ phenylhydrazine ( $\mathrm{pH} \mathrm{7.4)}$ per mouse on three consecutive days. Five or six days after the first injection, blood was drawn and collected on acid citrate/dextrose. The percentage reticulocytes was determined by brilliant kresylblue staining of the cells as described by Merck [15].

Reticulocytes were washed three times with $0.9 \% \mathrm{NaCl}$ containing $5 \mathrm{mM}$ glucose, resuspended in the desired buffer and used for experiments immediately.

\section{Cell fractionation}

The procedure used for the fractionation of DMSO-Friend cells is essentially the same as the procedure for the fractionation of undifferentiated Friend cells. Marker enzyme assays for subcellular fractions were carried out using established procedures: 5'-nucleotidase (EC 3.1.3.5) [16], alkaline phosphodiesterase I (EC 3.1.4.1) [17] and alkaline phosphatase (EC 3.1.3.1) [16] for plasma membranes; NADH-diaphorase (EC 1.6.99.3) [18] and 
antimycin-insensitive NADH-cytochrome $c$-reductase (EC 1.6.2.4.) [17] for microsomes; succinate dehydrogenase (EC 1.3.99.1) [19] for mitochondria and for lysosomes the enzymes $\beta$ D-glucuronidase (EC 3.2.1.31) [17] and $\beta$ - $N$-acetylD-glucosaminidase (EC 3.2.1.30) [20].

\section{Phospholipases}

Bee venom phospholipase $A_{2}$ (EC 3.1.1.4) was purified from crude bee venom [21]. Phospholipase C from Bacillus cereus was prepared according to Little [22]. Sphingomyelinase $\mathrm{C}$ from Staphylococcus aureus was purified as described by Zwaal et al. [23]. All the above mentioned enzymes were stored at $-20^{\circ} \mathrm{C}$ in buffered $(\mathrm{pH}$ 7.5) $50 \%$ glycerol.

Lys-116- $\beta-N$-palmitoyl-Amprec-8 was prepared from porcine pancreatic phospholipase $A_{2}$ as described by Slotboom et al. [24]. It was activated with trypsine to give lys-116- $\beta-N$-palmitoylAmpa-8 (pal-AMPA-8) just before use.

\section{Phosphatidylcholine transfer protein}

This protein was prepared from bovine liver and purified according to Westerman et al. [25]. Before use, the required amount of transfer protein was dialyzed against adequate buffer to remove glycerol and concentrated to the original volume over polyethyleneglycol flakes (Calbiochem).

\section{Phospholipase treatments}

All incubations were carried out at $37^{\circ} \mathrm{C}$ in a shaking water bath. Friend cells were resuspended in buffer $\mathrm{A}(150 \mathrm{mM} \mathrm{NaCl}, 5 \mathrm{mM} \mathrm{KCl}, 1 \mathrm{mM}$ $\mathrm{MgCl}_{2}, 1 \mathrm{mM} \mathrm{CaCl}, 5 \mathrm{mM}$ glucose and $20 \mathrm{mM}$ Tricine, $\mathrm{pH}$ 7.4). Incubations were started by the addition of enzymes (10 I.U. of phospholipase C, 2 I.U. of phospholipase $A_{2}$ or 0.5 I.U. of sphingomyelinase $\mathrm{C}$ per $10 \cdot 10^{6}$ cells). For each time point, samples contained $60 \cdot 10^{6}$ cells (corresponding to about $750 \mathrm{nmol}$ of lipid phosphorus) in a volume of $6 \mathrm{ml}$.

Mouse reticulocytes were also resuspended in buffer $A$. Incubations were started by addition of enzymes (40 I.U. of phospholipase C, 4-10 I.U. of phospholipase $A_{2}, 10$ I.U. of pal-AMPA-8 or 3 I.U. of sphingomyelinase $C$ per $0.150 \mathrm{ml}$ of packed cells (corresponding to about $650-700 \mathrm{nmol}$ of lipid phosphorus) in a volume of $6 \mathrm{ml}$.

Incubations were terminated by mixing the samples $(6 \mathrm{ml})$ with $1 \mathrm{ml}$ of $35 \mathrm{mM}$ ethylenediaminetetraacetic acid (EDTA) in buffer $A$ (for phospholipase $\mathrm{A}_{2}$ and sphingomyelinase $\mathrm{C}$ ) or with $1 \mathrm{ml}$ of $30 \mathrm{mM}$ EDTA plus $30 \mathrm{mM}$ o-phenanthroline in buffer A (for phospholipase C).

\section{Fluorescamine labeling of aminophospholipids}

DMSO-Friend cells were treated with increasing amounts of fluorescamine at low temperature $\left(0-4^{\circ} \mathrm{C}\right)$, exactly as described elsewhere [26]. Mouse reticulocytes were labeled at $15-30^{\circ} \mathrm{C}$ by using the same procedure, except that the labeled cells were diluted 5-fold with $6 \mathrm{mM}$ glycylglycine in buffer $\mathrm{A}(\mathrm{pH} 8)$ as quenching agent.

\section{Incubation with phosphatidylcholine transfer protein}

Friend cells were washed three times with Hank's balanced salt solution. Reticulocytes were washed three times with buffer $B(150 \mathrm{mM} \mathrm{NaCl}$, $5 \mathrm{mM} \mathrm{KCl}, 5 \mathrm{mM} \mathrm{NaHCO}, 1 \mathrm{mM}$ EDTA, $5 \mathrm{mM}$ glucose and $20 \mathrm{mM}$ Tricine, $\mathrm{pH}$ 7.4). Rat liver microsomal membranes were isolated from Wistar rats which had been injected intraperitoneally with $30 \mu \mathrm{Ci}$ of $\left[\right.$ methyl $-{ }^{14} \mathrm{C}$ ]choline [27]. Before use, they were sonicated in buffer $\mathrm{B}$ at $0^{\circ} \mathrm{C}$ using a Branson sonifier $(60 \mathrm{~W})$ untill the suspension became opalescent (usually 2 min). Remaining large particles were spun down at $8000 \times g$ for $10 \mathrm{~min}$. The supernatant was used for the incubations. Cells, microsomes and phosphatidylcholine (PC) transfer protein were preequilibrated at $37^{\circ} \mathrm{C}$ for 5 min.

All incubations were carried out at $37^{\circ} \mathrm{C}$ in a thermostated room on a clinical blood rotator at 4 rpm, incubations were started by the addition of microsomes to a cell suspension containing $4 \cdot 10^{7}$ Friend cells $/ \mathrm{ml}$ or $20-30 \%(\mathrm{v} / \mathrm{v})$ reticulocytes and 3-4 $\mu \mathrm{M}$ PC transfer protein in the appropriate buffer. The molar ratio of microsomal to cell $P C$ was about $1: 2$. As a control, equal amounts of cells and microsomes without PC transfer protein were incubated under the same conditions. At timed intervals, samples were taken and diluted 10 -fold in appropriate buffer at $37^{\circ} \mathrm{C}$. Cells were isolated by centrifugation at $2500 \times \mathrm{g}$ for $5 \mathrm{~min}$, and the supernatants were used to measure the 
extent of cell lysis. The cells were washed another two times with buffer to remove microsomal membranes before lipid extraction. The extent of PC exchange was calculated as described by Van Meer and Op den Kamp [28].

\section{Control of cell lysis}

The extent of cell lysis induced by the above mentioned treatments was determined by monitoring the hemoglobin release from reticulocytes and by assaying the release of lactate dehydrogenase (EC 1.1.1.27) from Friend cells. The diluted cells were centrifuged for $5 \mathrm{~min}$ at $2200 \times \mathrm{g}$. The amount of lactate dehydrogenase in the supernatant was compared to that found in this cell suspension before centrifugation; the latter value was taken as $100 \%$. The reaction mixture contained $42 \mathrm{mM}$ potassium phosphate buffer $(\mathrm{pH}$ 7.6), $0.9 \mathrm{mM}$ sodium pyruvate, $0.2 \mathrm{mM} \mathrm{NADH}$, $0.1 \%$ Triton $\mathrm{X}-100$ and the sample $(0.050 \mathrm{ml}$ cell suspension and up to $0.500 \mathrm{ml}$ supernatant) in a total volume of $3 \mathrm{ml}$. The linear rate of $\mathrm{NADH}$ oxidation was followed at $340 \mathrm{~nm}$ during $2 \mathrm{~min}$.

\section{Lipid extractions}

Friend cell pellets were extracted according to Reed et al. [29] after resuspension in $0.5 \mathrm{ml}$ of buffer A containing the appropriate inhibitors (see above) to ensure that no additional hydrolysis would occur during extraction. Mouse reticulocytes were extracted by the method of Rose and Oklander [30], using the same precautions. All lipid extracts were subjected to a wash according to Folch et al. [31].

\section{Analytical procedures}

The phospholipid composition of each lipid extract was determined by two-dimensional thinlayer chromatography [32], followed by phosphorus determination of the individual phospholipid spots [33]. Radioactivity was measured in 299TM emulsifier scintillator solution from Packard, using a Packard-PRIAS-Tricarb scintillation counter.

\section{Results}

For sake of clarity, the results concerning DMSO-Friend cells and mouse reticulocytes will be dealt with in separate sections. The data will be compared with the results of previously published experiments with undifferentiated Friend cells and mature mouse erythrocytes [13].

\section{TABLE I}

RELATIVE ABUNDANCE OF EACH PHOSPHOLIPID CLASS IN THE PLASMA MEMBRANES OF NATIVE FRIEND CELLS (F) AND DMSO-TREATED FRIEND CELLS (D)

In the left halve of the table the phospholipid compositions of whole cells and plasma membranes are present. In the right halve of the table the amount of each phospholipid class which is recovered in the plasma membrane is presented in two ways: as percentage of the total amount of phospholipid present in the whole cell (left) as well as the percentage of each phospholipid class present. The data for Friend cells (F) are taken from Ref. 12.

\begin{tabular}{|c|c|c|c|c|c|c|c|c|}
\hline \multirow[t]{3}{*}{$\begin{array}{l}\text { Phospho- } \\
\text { lipid }\end{array}$} & \multicolumn{4}{|c|}{ Composition (mole $\%$ ) in } & \multicolumn{4}{|c|}{$\begin{array}{l}\text { Amount of each phospholipid class in plasma } \\
\text { membrane }\end{array}$} \\
\hline & \multicolumn{2}{|l|}{ cells } & \multicolumn{2}{|c|}{ plasma membranes } & \multicolumn{2}{|c|}{$\begin{array}{l}\text { of total } \\
\text { phospholipid }\end{array}$} & \multicolumn{2}{|c|}{$\begin{array}{l}\% \text { of phospho- } \\
\text { lipid class }\end{array}$} \\
\hline & $\bar{F}$ & $\mathrm{D}$ & $\vec{F}$ & $\bar{D}$ & $\bar{F}$ & $\mathrm{D}$ & $\overline{\mathrm{F}}$ & $\mathrm{D}$ \\
\hline PC & 59.9 & 60.0 & 55.2 & 55.5 & 21.2 & 22.8 & 35.8 & 38.0 \\
\hline PE & 18.5 & 18.0 & 16.5 & 17.1 & 6.3 & 7.0 & 34.3 & 39.1 \\
\hline SPH & 5.6 & 5.7 & 10.2 & 9.9 & 4.0 & 4.1 & 70.7 & 71.4 \\
\hline PI & 8.3 & 8.0 & 5.3 & 2.3 & 2.3 & 2.3 & 27.6 & 28.0 \\
\hline PS & 4.0 & 4.2 & 10.6 & 10.5 & 4.1 & 4.3 & 103.0 & 103.0 \\
\hline LPC & 0.7 & 0.6 & 1.4 & 1.7 & 0.5 & 0.6 & 77.6 & 90.1 \\
\hline DPG & 3.0 & 3.5 & n.d. & n.d. & & & & \\
\hline Total & 100.0 & 100.0 & 100.0 & 100.0 & 38.4 & 41.1 & & \\
\hline
\end{tabular}




\section{Friend cells}

Friend cells before and after DMSO induction possess a considerable amount of intracellular membranes. Consequently, the phospholipid complement of the Friend cells plasma membrane must be known before any comparison can be made with the erythrocyte membrane. In a previous report, it has been described how plasma membranes of undifferentiated Friend cells can be isolated [12]. The same procedure has been applied on the DMSO-Friend cells and the results are similar to those published previously for the undifferentiated Friend cells [13]. The phospholipid composition of the purified plasma membrane was determined as well as the amount of total cellular phospholipid which is present in the plasma membrane of the cells. To achieve this, two independent techniques (non-lytic treatment of Friend cells with sphingomyelinase $C$ [12] and fluorescamine labelling [26]) were applied in a series of experiments as described by Chap et al. [34]. The data thus derived allowed us to calculate the phospholipid content and composition of the plasma membrane of differentiated Friend cells (Table I). For comparison, the data obtained with undifferentiated cells are presented as well. It is interesting to note that some phospholipids are mainly (lysophosphatidylcholine and sphingomyelin) or exclusively (phosphatidylserine) present in the plasma membrane of both untreated and DMSO-induced Friend cells, whereas phosphatidylinositol appears to be predominantly located in intracellular membrane systems.

\section{A. Treatment with phospholipases}

Phospholipase $\mathrm{A}_{2}$ treatment of DMSO-Friend cells resulted in the hydrolysis of $16-130 \%$ of the PC and $17-19 \%$ of the PE and caused a maximum cell lysis of $5-7 \%$ only. PI was hydrolyzed to a comparable extent, although a plateau was less clearly defined in this case. A semilogarithmic plot of the hydrolysis data (not shown) indicated that $15-17 \%$ of the cellular PI in DMSO-Friend cells was degraded under these conditions. On the other hand, the PS content of DMSO-Friend cells remained unaltered. The comparison of the results with the data obtained with undifferentiated cells show little or no change in the phospholipid distri- bution due to the DMSO treatment.

When Friend cells were treated with phospholipase C, approximately $15-17 \%$ of the PC, $12-15 \%$ of the PE and $5-7 \%$ of the PS plus PI were degraded. Sphingomyelinase $\mathrm{C}$ treatment resulted in the degradation of $56 \%$ of the sphingomyelin. In differentiated Friend cells, the hydrolysis of glycerophospholipids was found to be slightly higher than in native cells. Since pure phospholipase C from Bacillus cereus is essentially unable to degrade PI [3], the degradation of 5-7\% of the anionic phospholipids should account for the hydrolysis of PS only, which thus corresponds to $15-20 \%$ of the total amount of this phospholipid present in the cell.

Since the integrity of the cells was essentially conserved during these treatments, it is likely that the observed hydrolysis patterns reflect the degradation of the phospholipids present in the outer monolayer of the plasma membrane. The plateau values for hydrolysis which are already reached after $20 \mathrm{~min}$ of incubation, did not change during a subsequent incubation of two hours, suggesting that (with the possible exception of PI) all phospholipids present in the outer monolayer may have been degraded and that no transbilayer movement of phospholipid molecules from the inner to the outer face of the plasma membrane occurs in the time scale of the experiments.

\section{B. Fluorescamine labeling of aminophospholipids}

Rawyler et al. [26] investigated the conditions under which the permeant probe fluorescamine can be used to completely localize PE in intact Friend cells. Under the same conditions, DMSOFriend cells could be characterized with respect to PE localization. Semilogarithmic plots of the analytical data revealed that PE in Friend cells is present in three pools, representing the PE in the outer and inner monolayers of the plasma membrane as well as that in the intracellular membrane systems (Fig. 1). The relative sizes of these pools have been determined to be 16-18\%, 16-20\% and $64-66 \%$ of the total cell PE, respectively. The slightly decreased content of intracellular PE in DMSO-Friend cells compared to that in untreated Friend cells reflects the decreased content of intracellular phospholipid in DMSO-Friend cells (Table I). About $40 \%$ of the PE is present in the 


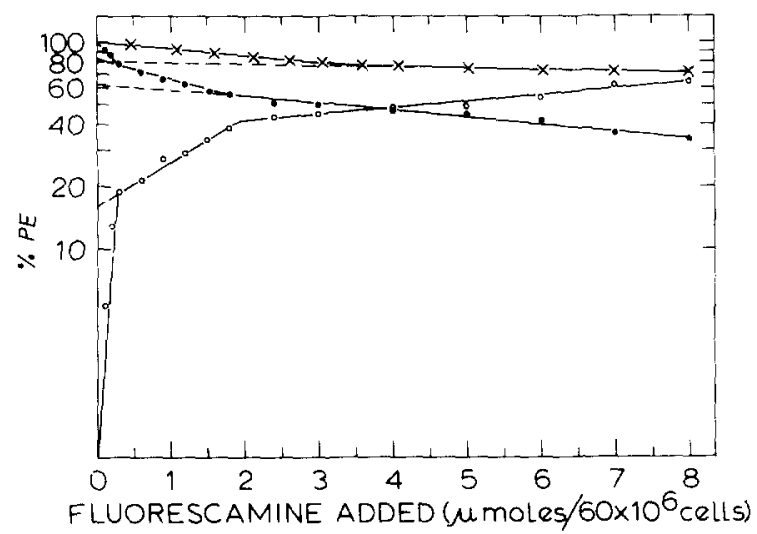

Fig. 1. Concentration-dependent labeling of aminophospholipids by fluorescamine. The conversion of $\mathrm{PE}$ present in DMSO-Friend cells $(O)$, into its fluorescamine derivative is determined as described in Materials and Methods. Also the corresponding decrease in PE is measured (๑), as well as the decrease in PE following fluorescamine treatment of mouse reticulocytes $(x)$. The data are expressed as $\%$ of the initial amount of PE. Cell lysis was less than $5 \%$ for all fluorescamine concentrations.

plasmalogen form, but its distribution over the different pools of PE is unknown. From further studies, it appeared that the labeling of PS is about six times less efficient than that of PE. Still, two pools could be observed. The first comprised $9-10 \%$ of the PS and can be attributed to the outer monolayer of the plasma membrane, while the second, slow-reacting pool represents the progressive labeling of the inner PS.

\section{Protein-catalyzed transfer of phosphatidylcholine}

Friend cell were incubated with $\left[{ }^{14} \mathrm{C}\right] \mathrm{PC}$-labeled rat liver microsomal membranes and $\mathrm{PC}$-specific exchange protein, essentially as described under Materials and Methods. The transfer of $\left[{ }^{14} \mathrm{C}\right] \mathrm{PC}$ from microsomes to Friend cells was determined and used to calculate the amount of PC in the outer leaflet of the Friend cell which is accessible for the exchange process [28]. About 19\% of the total cell PC in Friend cells appeared to be exchangeable during a $4 \mathrm{~h}$ incubation period, and no additional exchange, at least not at a measurable rate, occurred afterwards (Fig. 2). The increased exchange of PC in DMSO-Friend cells compared to that in Friend cells reflects the decreased content of intracellular phospholipid in DMSO-Friend cells.

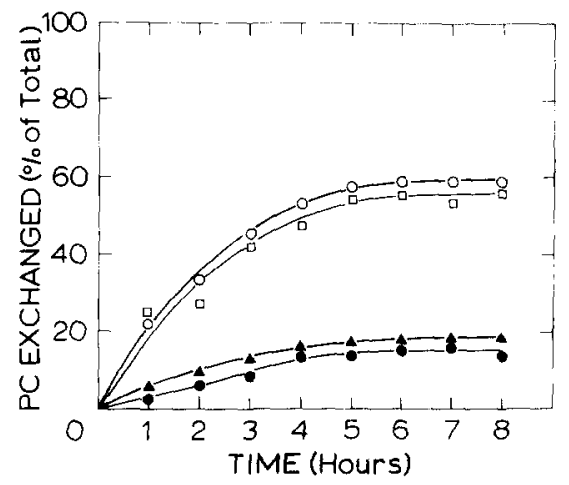

Fig. 2. Exchangeability of PC from DMSO-Friend cells (ム) and reticulocytes $(O)$. The $P C$-specific transfer protein was used to exchange $P C$ between labeled rat liver microsomes and the plasma membranes of DMSO-Friend cells ( $\Delta$ ) and reticulocytes $(O)$ as described in the text. The data are expressed as $\%$ of the total amount of PC present in the cells. For comparison, the exchange profiles obtained with Friend cells $(\bullet)$ and mature erythrocytes $(\square)$ are plotted.

D. Transbilayer distribution of phospholipids in the plasma membrane of Friend cells

Table II summarizes the results of the above experiments concerning DMSO-Friend cells and shows the corresponding data for the cells before differentiation. The amount of each phospholipid, detectable with the various techniques under nonlytic conditions, is expressed both as the percentage of the cellular content of each phospholipid class and as the percentage of total cell phospholipid. All techniques gave comparable values for each phospholipid. It can be calculated, by adding up the figures given in Table II, lines $b$, that for Friend cells the outer monolayer of the plasma membrane accounts for $15.8-19.7 \%$ of the total cell phospholipid, averaging at $17.8 \%$. The plasma membrane contains $38.4 \%$ of the total cell phospholipid (Table I). Thus, it can be concluded that the inner monolayer of the plasma membrane is only slightly enriched in phospholipid (54\%) compared to the outer monolayer (46\%).

In DMSO-Friend cells, the outer monolayer of the plasma membrane accounts for $16.1-21.0 \%$ of the total cell phospholipid, averaging at $18.6 \%$. The plasma membrane of these cells contains $41.1 \%$ of the total cell phospholipid (Table I). Also in these cells, the inner monolayer of the plasma membrane is slightly enriched in phospholipid 
TABLE II

AVAILABILITY OF PHOSPHOLIPIDS TO DIFFERENT REAGENTS IN NATIVE FRIEND CELLS (F) AND DMSO-FRIEND CELLS (D)

Data are expressed as percentage of each phospholipid class (lines a) and as percent of total cell phospholipid (lines b).

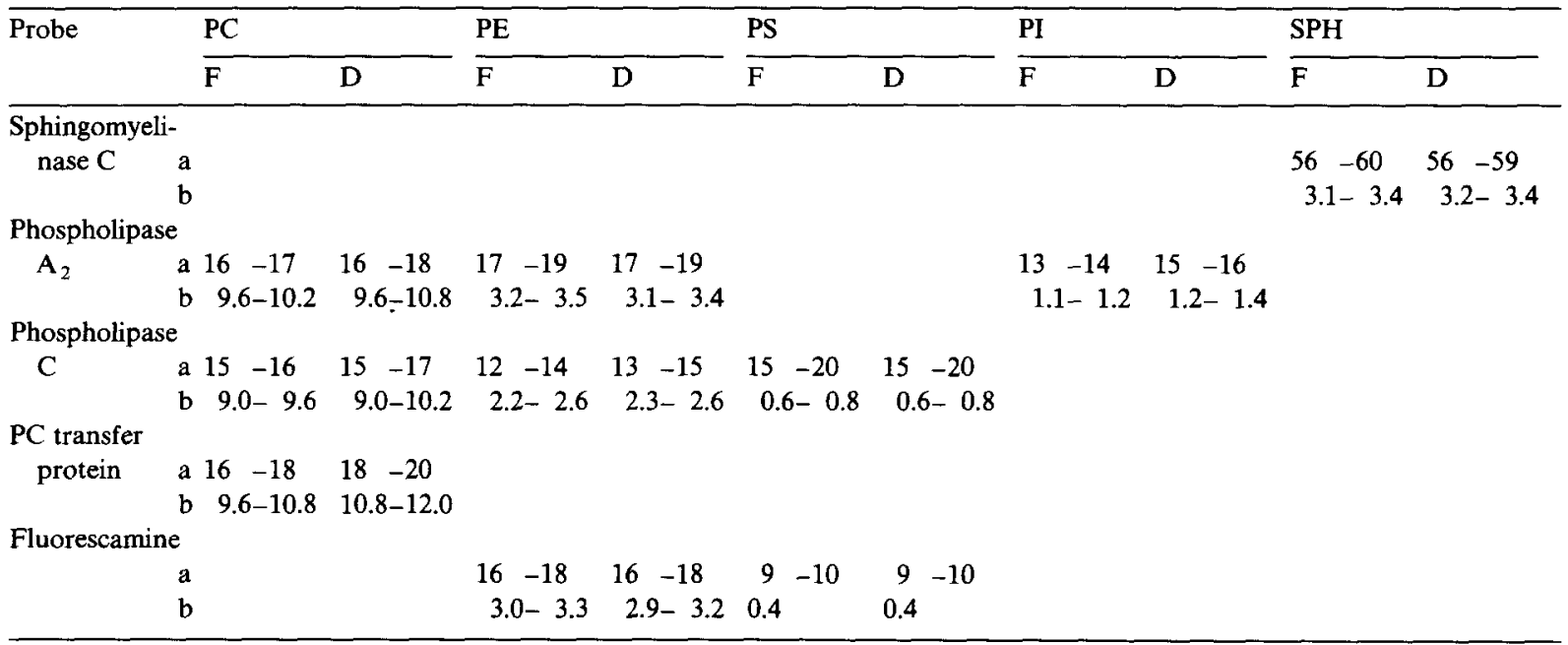

TABLE III

RELATIVE AMOUNTS OF FRIEND CELLS (F), DMSO-FRIEND CELLS (D) AND RETICULOCYTE (R) PLASMA MEMBRANE PHOSPHOLIPIDS PRESENT IN THE OUTER MONOLAYER

Data are expressed as the percentage of the total amount of each phospholipid class present in the plasma membrane. These values are calculated by using the relative abundance data of Table I, last two columns, and the data on the relative availability of each phospholipid class for exogenous probes (Table II, lines a). The phospholipid composition (mol\%) of mouse reticulocytes is $47.0 \%$ phosphatidylcholine, $25.9 \%$ phosphatidylethanolamine, $12.4 \%$ sphingomyelin, $8.8 \%$ phosphatidylserine, $3.4 \%$ phosphatidylinositol and $2.5 \%$ lysophosphatidylcholine.

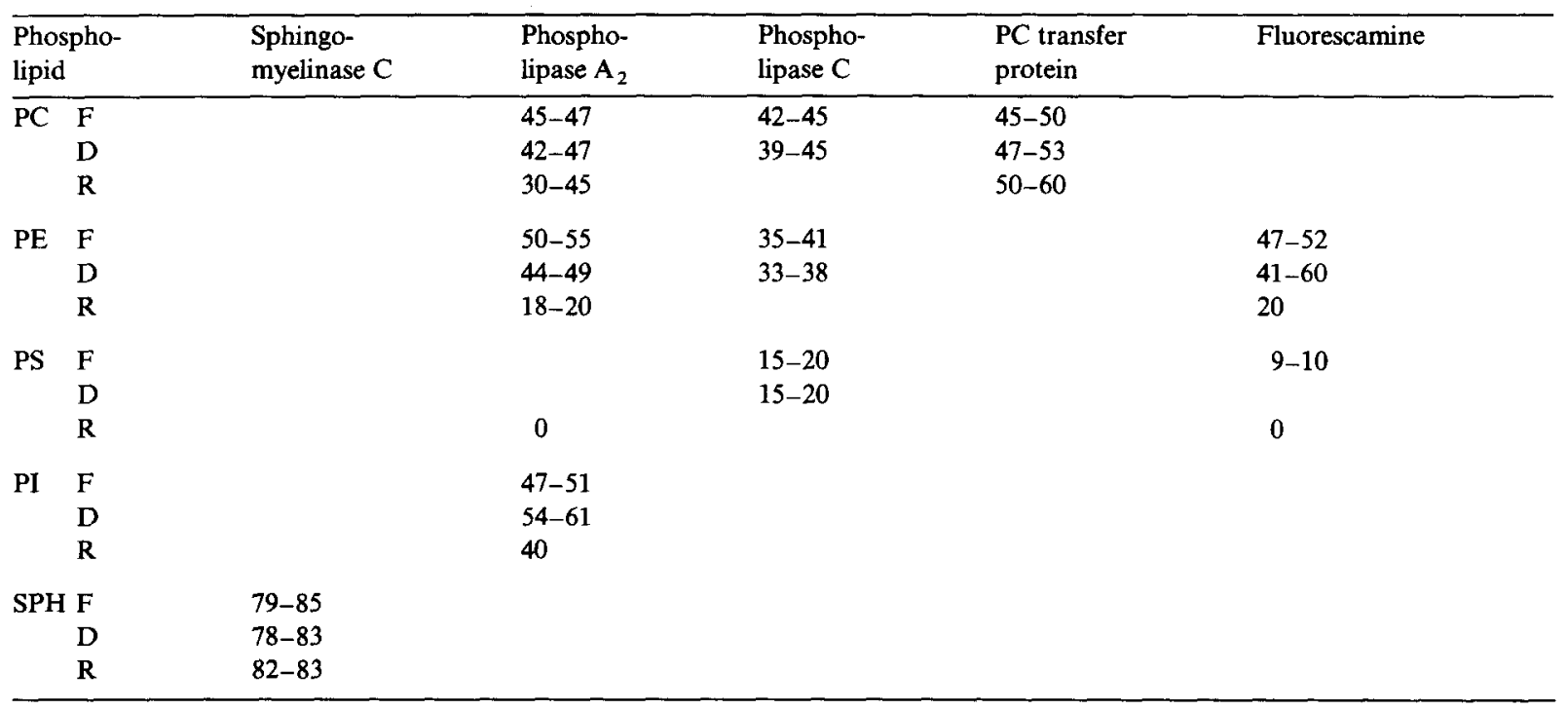


(55\%) compared to the outer monolayer (45\%). From the data given in Tables I (last two columns) and II (lines a), one can calculate for each phospholipid class which fraction of its total amount in the plasma membrane is present in the outer monolayer. Results of such calculations are summarized in Table III for Friend cells, both before and after differentiation. It can be seen that in both types of Friend cells the two major phospholipids of the plasma membrane, $\mathrm{PC}$ and $\mathrm{PE}$, are essentially symmetrically distributed over the two monolayers. A similar arrangement can be tentatively proposed for PI, be it that the experimental evidence is less conclusive. On the other hand, the plasma membrane is strongly asymmetric with respect to the distribution of sphingomyelin ( $80-85 \%$ outside) and PS (10-20\% outside).

\section{Mouse reticulocytes}

Treatment of mice with phenylhydrazine resulted in a level of $60-95 \%$ reticulocytes, relative to the total red cell population, as determined by brilliant kresylblue staining of the cells.

\section{A. Treatment with phospholipases}

Reticulocytes were incubated at $37^{\circ} \mathrm{C}$ in the presence of sphingomyelinase $\mathrm{C}$, phospholipase $\mathrm{A}_{2}$ or a combination of both enzymes. Sphingomyelinase $\mathrm{C}$ degraded $82-83 \%$ of the sphingomyelin and a well defined plateau in the hydrolysis profile was obtained. Hemolysis could be limited to $5 \%$. One can conclude from this result that sphingomyelin is distributed in an asymmetric way in the mouse reticulocyte membrane, $82-83 \%$ being present in the outer leaflet and $17-18 \%$ in the inner leaflet of the plasma membrane.

When mouse reticulocytes were subjected to phospholipase $\mathrm{A}_{2}$ treatment, the degradation of glycerophospholipids was limited to $20-30 \%$ of the PC and $8-15 \%$ of the PE. No hydrolysis of anionic phospholipids occurred and hemolysis did not exceed 5\%. Incubation of mouse reticulocytes with a combination of phospholipase $\mathrm{A}_{2}$ and sphingomyelinase $C$ resulted in $30-45 \%$ PC hydrolysis, 18-20\% PE hydrolysis and 10-12\% hydrolysis of anionic phospholipids, during which hemolysis was limited to $6-9 \%$. These data imply that a maximum of $38 \%$ of the total phospholipids can be degraded in intact reticulocytes. On the other hand, the experiment with the PC-specific transfer protein shows that $50-60 \%$ of the total $\mathrm{PC}$ is present in the outer monolayer. A similar set of conflicting results had been obtained for mature mouse erythrocytes [13]. The incomplete hydrolysis of the PC in this membrane has to be ascribed to a tight packing of the phospholipids in the outer monolayer. Hence, only a phospholipase $\mathrm{A}_{2}$ with an extremely high penetration capacity, such as the modified pancreatic phospholipase pal-AMPA-8 [24], was able to hydrolyse all of the PC present in the outer monolayer (results not shown).

\section{B. Experiments with phosphatidylcholine transfer protein}

Monolayer experiments have shown that the PC transfer protein is able to exchange its substrate up to the collapse pressure of the mono-

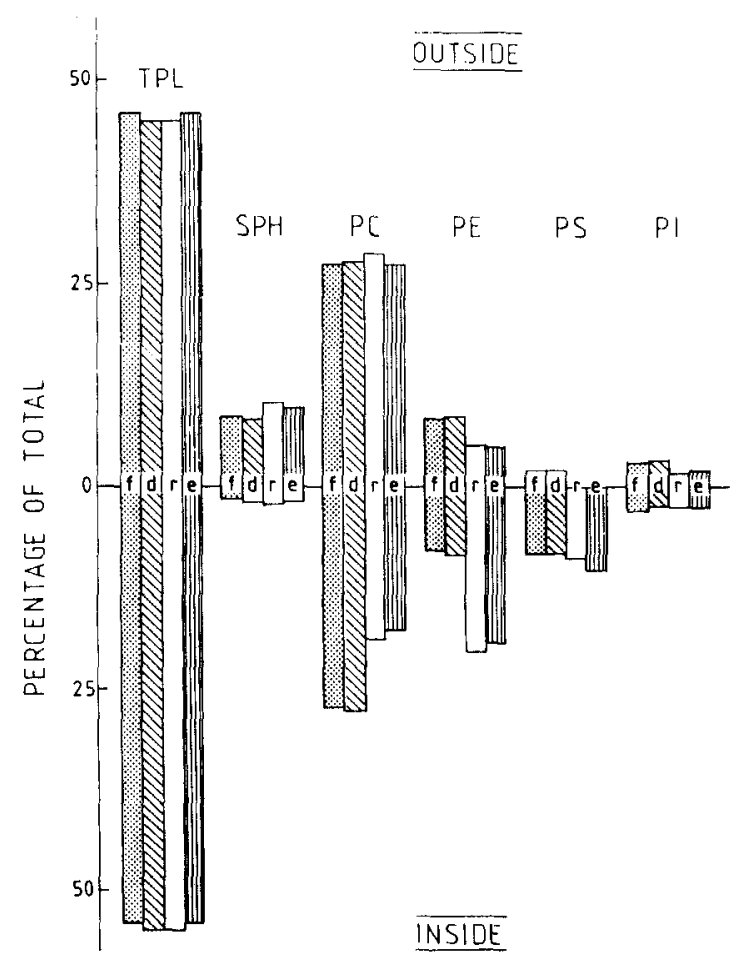

Fig. 3. Phospholipid composition and transbilayer distribution in plasma membranes of Friend cells before ( $f$ ) and after (d) differentiation, mouse reticulocytes (r) and mature mouse erythrocytes(e). 
molecular film (Kuypers, F.A., unpublished results). This property is attractive in view of the equivocal data obtained for the localization of PC using phospholipase $\mathrm{A}_{2}$. Indeed, incubation of mouse reticulocytes with $\left[{ }^{14} \mathrm{C}\right] \mathrm{PC}$-labeled microsomes and PC-specific exchange protein resulted in an exchange of $50-60 \%$ of the total PC present in the plasma membrane (Fig. 2). The residual PC does not become accessible for the exchange protein in prolonged incubations (up to $8 \mathrm{~h}$ ) which indicates that $50-60 \%$ of the total PC is present in the outer monolayer, the remainder being at the inside [35].

\section{Fluorescamine labeling of aminophospholipids}

Chemical labeling of aminophospholipids in the reticulocyte membrane with fluorescamine was undertaken to study the localization of these phospholipids. PS was labeled as one slow reacting pool as in mouse erythrocytes, extrapolating to 98-100\% (data not shown). The labeling pattern of PE was obviously biphasic. The extrapolation of the second linear component of residual PE yielded a value of $80-85 \%$, which was confirmed by a complementary value of $15-20 \%$ for the corresponding fluorescamine derivative of PE (Fig. 1). These data confirm those obtained by enzyme treatment and show that the outer monolayer of the reticulocyte membrane is devoid of PS and contains only $20 \%$ of the PE.

Table III summarizes the results of all the above experiments concerning mouse reticulocytes. The outer monolayer contains $50-60 \%$ of the PC, $20 \%$ of the PE and $82-83 \%$ of the sphingomyelin. In addition, since no PS is present in the outer monolayer according to the fluorescamine labeling experiment, it can be extrapolated from the results of the hydrolytic enzyme experiment, that the $10-12 \%$ of anionic, degradable phospholipids represents the hydrolysis of PI only. On basis of these data and the phospholipid composition of mouse reticulocytes (see legend to Table III), one can calculate that the outer and inner monolayers contain, respectively, $46 \%$ and $54 \%$ of the total phospholipids.

\section{Discussion}

In the present study which deals with the biogenesis of red cell phospholipid asymmetry, we have concentrated on the composition and localization of phospholipids in the plasma membrane of the Friend cell. Part of this membrane will, at least in the in vivo counterpart of these cells, end up as the plasma membrane of a reticulocyte and consequently as that of the mature erythrocyte. It should be realised, however, that Friend cells are transformed cells and that no information is available on the effects transformation might have on the phospholipid organization. Nevertheless, these cells are considered to be a reliable model system and are frequently used to study erythropoiesis $[8,10]$. A similar comment has to be made concerning the reticulocytes isolated after phenylhydrazine treatment. Our studies deal with socalled 'stressed reticulocytes' and the effects that phenylhydrazine treatment might have on the membranes of native reticulocytes is unknown.

Evidence to underline the justification of the use of Friend cells in our studies comes from a series of experiments carried out with isolated and cultured murine erythroid progenitor cells. These cells, when cultured under the proper conditions, proceed through the differentiation pathway up to the final enucleation step $[6,7,36]$. It was shown that the distribution of $\mathrm{PE}$ in the plasma membrane of these cells, as measured with the very sensitive fluorescamine labeling assay [36], is completely identical to the distribution observed here for the Friend cell. Furthermore, it appeared to be obvious that this distribution did not change during the differentiation, at least not until a late normoblast stage was obtained. Due to the limited amount of cells which can be obtained by the isolation procedure as described by Nijhof et al. [36] we were unable to apply the usual phospholipid localization techniques to establish the distribution of the other major phospholipids. Therefore, we had to shift to Friend cells which can be obtained in much larger quantities. Differentiation of these cells was obtained by the addition of DMSO to the growth medium [10]. Under the conditions applied, differentiation proceeds up to a normoblast-like stage. The morphological and biochemical characteristics of their development program have been intensively investigated and in many respects closely resemble those of the normal erythropoietic pathway $[9,10]$. In addition, we have studied the reticulocytes from mice, en- 
hanced production of which had been induced by phenylhydrazine treatment of the animals. The data are compared with previously published results of studies on undifferentiated Friend cells and mature mouse erythrocytes, respectively.

DMSO treatment has no effect on the phospholipid composition of the cells, neither does it affect the distribution of the lipids over the various membrane fractions, nor their asymmetric disposition in the plasma membrane. The results obtained with the various localization techniques are straightforward to interpret and the data obtained from the various independent approaches were in good agreement with one another.

The asymmetric phospholipid distribution in the reticulocyte membrane is identical to that in the membrane of the mature erythrocyte. Even the packing characteristics of one of the major phospholipids, PC, seem to be similar in both systems as judged from the limited hydrolysis with phospholipases. The failure of phospholipase $A_{2}$ (either from snake or bee venom) to degrade all of its substrates present in the outer membrane layer of an erythrocyte has been well documented for the human red cell $[3,23]$. It has been argued [37] that the action of the phospholipase $\mathrm{A}_{2}$ ceases as a consequence of an increase in lateral surface pressure in the outer monolayer of the intact cell, which is caused by the generation of split products (lysophospholipids and free fatty acids) herein. Hydrolysis of sphingomyelin by sphingomyelinase $\mathrm{C}$ is believed to have the opposite effect, namely, a decrease in lateral surface pressure [3,37]. Including this enzyme in incubations with phospholipase $A_{2}$, therefore, enables the latter phospholipase to degrade its substrates in the outer monolayer of intact human erythrocytes to completion $[3,23]$. However, the combined action of phospholipase $A_{2}$ plus sphingomyelinase $C$ (the latter enzyme being added $10 \mathrm{~min}$ after the addition of phospholipase $\mathrm{A}_{2}$ ) on mouse erythrocytes did not increase the extent of glycerophospholipid hydrolysis during a 1-h incubation period. This may be due to the relatively low sphingomyelin content of the mouse erythrocyte when compared to the human red cell, making the sphingomyelinase $\mathrm{C}$-induced decrease in lateral surface pressure too limited to give the phospholipase $\mathrm{A}_{2}$ an additional chance. Another possibility to achieve a decrease in packing pressure in the outer monolayer may be found in removal of hydrolysis products with bovine serum albumin [38]. This approach did not result in any further degradation of the $\mathrm{PC}$ in this membrane. As yet, we have no explanation for this remarkable finding. On the other hand, palAMPA- 8 treatment of mouse erythrocytes resulted in the complete hydrolysis of PC in the outer monolayer. This modified porcine pancreatic phospholipase $A_{2}$ is able to penetrate into the outer monolayer by means of its palmitic acid residue coupled to Lys-116. Recently, it was shown that this enzyme can degrade all PC present in the outer monolayer of the intact human erythrocyte at a much higher rate and with even greater efficiency than by the best penetrating Naja naja phospholipase $\mathrm{A}_{2}$ isoenzyme [39].

A conclusion to be drawn from this and previous studies is that a remarkable asymmetric distribution of only two of the major phospholipids occurs already at an early stage of erythropoiesis. Sphingomyelin is nearly completely present in the outer layer whereas PS is present in the inside membrane leaflet. In other plasma membranes investigated sofar $[1,40]$, this asymmetry also occurs, but much less expressed than in the case of the erythroid cells. The data furthermore show that the phospholipid composition of the plasma membrane of the early precursor cell is almost identical to that of the reticulocyte and erythrocyte. This suggests that enucleation, the process at which $90 \%$ of the plasma membrane is removed and only $10 \%$ is recovered as reticulocyte membrane, does not involve a specific sorting of phospholipid molecules but is, instead, accompanied by a random release of phospholipid material. On the other hand, no detailed information is available on the fatty acyl constituents of the phospholipids of the plasma membrane of proerythroblasts and normoblasts. This still leaves the possibility open that a segregation of molecular species of the membrane phospholipids accompanies enucleation. Furthermore, the data concerning the lipid localization in the plasma membranes of the cells before and after enucleation also indicate the occurrence of some extent of lipid segregation, or at least a specific and selective retention of some phospholipids in the inner and outer layer, respectively. One may speculate that in case 
the plasma membrane of Friend cells, both before and after differentiation of those cells, has a phospholipid distribution which is comparable to that in the plasma membrane of their normal nontransformed counterparts, changes must occur in the distribution of PC, PE and PS in the plasma membrane during erythropoiesis, especially between the normoblast and reticulocyte stage of differentiation (Fig. 3). PI and sphingomyelin, however, are already distributed in the Friend cell plasma membrane in a way identical to that in the reticulocyte and erythrocyte membrane. The latter observation once more emphasizes the very special place sphingomyelin appears to occupy among the phospholipids in the red cell membrane. In contrast to (some of) the glycerophospholipids, the most pronounced asymmetric distribution of sphingomyelin is altered neither in chemically modified normal human erythrocytes [41] nor in sickled erythrocytes [42]. Furthermore, it was recently found that, unlike PC and PE, the sphingomyelin in the (human) red cell membrane possess a high degree of asymmetry in the composition of its molecular species at either side of the membrane, indicating the virtual absence of transbilayer movements of this phospholipid [43]. In this context, is is relevant to recall that in plasma membranes of various other cell types, e.g. BHK [40] and MDBK cells [44], sphingomyelin adopts another, less asymmetric, transbilayer distribution.

During differentiation from proerythroblast to normoblast, no changes in composition and transbilayer distribution of the glycerophospholipids are observed. On the other hand, many changes occur in this part of the differentiation pathway with respect to protein synthesis and composition of these cells. In view of the well established role the membrane skeleton, and in particular its spectrin, plays in the stabilization of phospholipid asymmetry in the red cell membrane [41], it is worth noting that Glenney and Glenney [45] have shown that Friend cells contain a very low level of spectrin. Upon DMSO-induced differentiation, however, spectrin synthesis increases and after four days of growth spectrin undergoes rearrangements into submembranous 'patches' and 'caps'. Still, this protein is not as abundant as in the mouse red blood cell. Recently, Koury et al. [46] showed that Friend cells not only contain a very low level of spectrin, but also very small amounts of band 3 and band 4.1 protein; a progressive increase in the amounts of these principal erythrocyte proteins occurs during terminal differentiation as induced by erythropoietin. Before enucleation of the normoblast, however, the levels of these proteins are still low compared to the erythrocyte.

As mentioned above, enucleation is accompanied by an enormous loss of plasma membrane phospholipid and only a small part of the normoblast plasma membrane will form the reticulocyte membrane. The reticulocyte membrane will loose an additional part of its phospholipid during its maturation to the erythrocyte. Probably this loss of phospholipid will take place during the remodelling of the reticulocyte as proposed by Zweig et al. [47]. This process only decreases the absolute amount of phospholipid and has no consequences for the phospholipid composition and distribution in the reticulocyte membrane. During enucleation of the normoblast, producing the reticulocyte, a most significant concentration of spectrin occurs, because all of the spectrin of the former cell is sequestered to the membrane of the reticulocyte $[47,48]$. The membrane of mouse reticulocytes shows a protein pattern upon SDSpolyacrylamide gel electrophoresis which is very similar to that of mature mouse erythrocytes [49]. However, the membrane skeleton is not quite fully formed [47] and protein synthesis is still going on in the reticulocyte [50]. Recently another mechanism has been postulated which is involved in the maintenance of phospholipid asymmetry in the red cell membrane, i.e. an ATP-dependent translocation of aminophospholipids towards the inner monolayer [51,52]. The present data should imply that this active transport system is not fully developed in the erythroid precursors. Further studies will be necessary to clarify this point.

This study shows that the final asymmetric distribution of PC, PE and PS coincides with the final formation of the membrane skeleton during enucleation of the normoblast and the release of the reticulocyte into the blood stream. Lipid-protein interactions, such as those of PS and PE with spectrin [41] might favor the increase in the inside: outside distribution ratio of these phos- 
pholipids. The complete translocation of PS from the outer to the inner half of the bilayer, as it appears to occur at this stage, seems to be a very essential prerequisite for the in vivo survival of the reticulocyte (and erythrocyte), because the presence of this phospholipid in the outer surface of the plasma membrane would cause a clearance of those cells from the blood stream [53].

\section{Acknowledgements}

The authors thank M. van Linde for the purification of the phospholipases and transfer protein, and Dr. A.J. Slotboom for his kind donation of pal-AMPA-8. The present investigations were carried out under the auspices of The Netherlands Foundation for Chemical Research (S.O.N.) and with financial aid from The Netherlands Organization for Advancement of Pure Research (Z.W.O.).

\section{References}

1 Op den Kamp, J.A.F. (1979) Annu. Rev. Biochem. 48, 419-448

2 Etemadi, A.H. (1980) Biochim. Biophys. Acta 604, 423-475

3 Roelofsen, B. (1982) J. Toxicol. Toxin Rev. 1, 87-197

4 Harrison, P.R. (1976) Nature (London) 262, 353-356

5 Friend, C. and Pogo, B.G.-T. (1985) Biochim. Biophys. Acta $780,181-195$

6 Troxler, D.H., Ruscetti, S.K. and Scolnick, E.M. (1980) Biochim. Biophys. Acta 605, 305-324

7 Kost, T.A., Koury, M.J., Hankins, W.D. and Krantz, S.B. (1979) Cell (Cambridge, MA) 18, 145-152

8 Friend, C., Scher, W., Holland, W.G. and Sato, T. (1971) Proc. Natl. Acad. Sci. USA 68, 378-382

9 Reuben, R.C., Rifkind, R.A. and Marks, P.A. (1980) Biochim. Biophys. Acta $605,325-346$

10 Marks, P.A. and Rifkind, R.A. (1978) Annu. Rev. Biochem. 47, 419-448

11 Rawyler, A.J., Roelofsen, B., Wirtz, K.W.A. and Op den Kamp, J.A.F. (1982) FEBS Lett. 148, 140-144

12 Rawyler, A.J., Roelofsen, B., Op den Kamp, J.A.F. and Van Deenen, L.L.M. (1983) Biochim. Biophys. Acta 730, 130-138

13 Rawyler, A., Van der Schaft, P.H., Roelofsen, B. and Op den Kamp, J.A.F. (1985) Biochemistry 24, 1777-1783

14 Rifkind, R.A., Fibach, E. and Marks, P.A. (1978) in In vitro aspects of erythropoiesis (Murphy, M.J., ed.), pp. 266-267, Springer Verlag, Berlin

15 Haematologische Labormethoden (1982) Merck, E., G.I.T. Verlag, Ernst Giebeler, pp. 15-16

16 Evans, W.H. (1979) in Laboratory techniques in biochemistry and molecular biology (Work, T.S. and Work, E., eds.), Vol. 6, pp. 1-259, North-Holland, Amsterdam
17 Aronson, N.N. and Touster, D. (1974) in Methods in Enzymology (Fleischer, S. and Packer, L., eds.), Vol. 31, Part A, pp. 90-102, Academic Press, New York

18 Kusaka, I. and Kitihara, K. (1967) Biochim. Biophys. Acta $148,558-560$

19 Earl, D.C.N. and Korner, A. (1965) Biochem. J. 94, 721-734

20 Kornfeld, R. and Siemens, C. (1974) J. Biol. Chem. 249, 1295-1301

21 Shipolini, R.A., Callewaert, G.L., Cottrel, R.C., Doonan, S., Vernon, C.A. and Banks, B.E.C. (1971) Eur. J. Biochem. $20,459-468$

22 Little, C. (1981) Methods Enzymol. 71, 175-179

23 Zwaal, R.F.A., Roelofsen, B., Comfurius, P. and Van Deenen, L.L.M. (1975) Biochim. Biophys. Acta 406, 83-96

24 Slotboom, A.J., Van Scharrenburg, G.J.M., Van der Wiele, F., Atsma, W. and De Haas, G.H. (1985) Proc. 9th APS (Deber, C.M., Hzuby, V.J. and Kopple, J.D., eds.) pp. 347-350, Pierce Chemical Company, Rockford, Il

25 Westerman, J., Kamp, H.H. and Wirtz, K.W.A. (1983) Methods Enzymol. 98, 581-586

26 Rawyler, A., Roelofsen, B. and Op den Kamp, J.A.F. (1984) Biochim. Biophys. Acta 769, 330-336

27 Kamp, H. and Wirtz, K.W.A. (1974) Methods Enzymol. 32, 140-146

28 Van Meer, G. and Op den Kamp, J.A.F. (1982) J. Cell. Biochem. 19, 193-204

29 Reed, C.F., Swisher, S.N., Marinetti, G.V. and Ede, E.G. (1960) J. Lab. Clin. Med. 56, 281-289

30 Rose, H.G. and Oklander, M. (1965) J. Lipid Res. 6, 429-431

31 Folch, J., Lees, M. and Sloane-Stanley, G.H. (1957) J. Biol. Chem. 226, 497-509

32 Broekhuyse, R.M. (1969) Clin. Chim. Acta 23, 457-461

33 Boettcher, C.J.F., Van Gent, C.M. and Pries, C. (1961) Anal. Chim. Acta 183, 203-208

34 Chap, H.J., Zwaal, R.F.A. and Van Deenen, L.L.M. (1977) Biochim. Biophys. Acta 467, 146-164

35 Van Meer, G., Poorthuis, B.J.H.M., Wirtz, K.W.A., Op den Kamp, J.A.F. and Van Deenen, L.L.M. (1980) Eur. J. Biochem. 103, 283-288

36 Nijhof, W. Van der Schaft, P.H., Wierenga, P.K., Roelofsen, B., Op den Kamp, J.A.F. and Van Deenen, L.L.M. (1987) Biochim. Biophys. Acta 862, 273-277

37 Roelofsen, B., Sibenius Trip, M., Verhey, H.M. and Zevenbergen, J.L. (1980) Biochim. Biophys. Acta 600, 1012-1017

38 Haest, C.W.M., Plasa, G. and Deuticke, B. (1981) Biochim. Biophys. Acta 649, 701-708

39 De Haas, G.H., Slotboom, A.J., Van Oort, M.G., Van der Wiele, F., Atsma, W., Van Linde, M. and Roelofsen, B. (1986) Adv. Exp. Med. Biol., in the press

40 Van Meer, G., Simons, K., Op den Kamp, J.A.F. and Van Deenen, L.L.M. (1981) Biochemistry 20, 1974-1981

41 Haest, C.W.M., Plasa, G., Kamp, D. and Deuticke, B. (1978) Biochim. Biophys. Acta 509, 21-32

42 Lubin, B., Chiu, D., Bastacky, J., Roelofsen, B. and Van Deenen, L.L.M. (1981) J. Clin. Invest. 67, 1643-1649

43 Boegheim, J.P.J., Van Linde, M., Op den Kamp, J.A.F. and Roelofsen, B. (1983) Biochim. Biophys. Acta 735, 438-442 
44 Rothman, J.E., Tsai, D.K., Dawidowicz, E.A. and Lenard, J. (1976) Biochemistry 15, 2361-2370

45 Glenney, J. and Glenney, P. (1984) Exp. Cell Res. 152, 15-21

46 Koury, M.J., Bondurant, M.C. and Mueller, T.J. (1986) J. Cell. Physiol. 126, 259-265

47 Zweig, S.E., Tokuyasu, K.T. and Singer, S.J. (1981) J. Supramol. Struct. Cell. Biochem. 17, 163-181

48 Geiduschek, J.B. and Singer, S.J. (1979) Cell (Cambridge, MA) 16, 149-163
49 Yuthavong, Y., Wilairat, P., Panypan, B., Potiwan, C. and Beale, G.H. (1979) Comp. Biochem. Physiol. 63B, 83-85

50 Bodine IV, D.M., Birkenmeier, C.S. and Barker, J.E. (1984) Cell (Cambridge, MA) 37, 721-729

51 Seigneuret, M. and Devaux, P.F. (1984) Proc. Natl. Acad. Sci. USA 81, 3751-3755

52 Tilley, L., Cribier, S., Roelofsen, B., Op den Kamp, J.A.F. and Van Deenen, L.L.M. (1985) FEBS Lett. 194, 21-27

53 Schroit, A.J., Madsen, J.W. and Tanaka, Y. (1985) J. Biol. Chem. 260, 5131-5138 